\title{
Chapter 3 \\ Summary of Main Research Findings: \\ India, Indonesia, Sri Lanka, Viet Nam
}

\begin{abstract}
Background and an overview of each of the four case study countries are presented. Details are provided and discussed regarding the main findings for each country regarding environmental policy frameworks, skills development efforts, industry and TVET roles and linkages, sector issues and main policy and practice recommendations, including for education and training. Implications for the business sector, TVET providers, and government are presented and discussed. Recommendations across all four case study countries are presented, discussed, and compared with particular reference to lessons learnt and emerging most effective practices.
\end{abstract}

Keywords India - Indonesia - Sri Lanka - Viet Nam • Environmental policy framework - Sustainable practices - TVET linkages - Sector issues • Integrated skills development • Promoting green and sustainable practices • Outcome-based incentives - Sustainability as a social issue $\cdot$ Green narrative $\cdot$ Industry awareness • Paradigm shift in skills development system • Outcome-based incentives • Green practices - Sustainability as a social issue - Downstream and upstream supply chains - Social development policies - Construction • Energy - Transport • Services - Manufacturing - Incentives to promote green skills • Green lines of credit • Private and government training systems • Informal sector • Rural sector • Industry and TVET linkages - Regulatory pressures - Direct and indirect incentives - Motivations and practices of foreign aid investment agencies - Generic content

This ADB research study on Education and Skills for inclusive Growth and Green jobs in Asia focused on examining four countries: India, Indonesia, Sri Lanka, and Viet Nam. The purpose of this chapter is to provide the storylines and a summary of the main findings for each country. Full details on each country case study are available at www.cna-qatar.com/research/unesco-unevoc. 


\section{India}

\subsection{Background and Overview}

The concept of "green jobs," or environmentally sustainable work, has existed in India since prehistoric times. The Vedic literature elaborates on conserving the panch tatvas (five elements - earth, water, fire, air, and sky), and many work practices in India, especially in rural areas, have been inspired from conserving the efficient use of the five elements.

However, modern economic activities, including those in agriculture, have been having an adverse impact on the environment and lack sustainable practices in work environments. While there are many shades of green in agricultural practices, these shades get diluted in industrial practices and urban settings. Although industries in India, especially large corporations, are sensitive about climate change issues, this sensitivity varies across sectors. While the renewable energy sector considers the sector itself to be "green" (which is not necessarily true, because many of the work practices may not be green), the manufacturing sector struggles to put the issue high on its agenda because of competitive and regulatory pressures and increasing costs. The services industry is more of a consumer of the other two economic sectors (agriculture and manufacturing) and therefore needs sensitization around the efficient use of energy, water, consumables, and waste management.

Individuals in smaller manufacturing units and in the informal sector are conscious of the importance of sustainable processes and practices, but in the absence of clear standards or a regulatory framework, the enthusiasm of individuals does not get translated into action at the institutional level, thus limiting the scope of green jobs. Nevertheless, the scope of green skills at all job levels is increasing and is being addressed by most industries.

The same holds true for TVET and skills development providers, who, in the absence of any accreditation or well-defined certification systems, are not clear about effective ways to integrate green skills courses into their programs. The highly regulated government TVET and skills development system does not recognize the scope for developing new programs until a regulatory order is established. Instead, they continue to implement traditional curricula and pedagogy even though the demands of industry are changing. The private TVET system, on the other hand, is much more dynamic and responsive to the demands of industry and has the ability and motivation to change programs, courses, and pedagogy to suit the needs of employers, because ultimately its survival depends on the employability of its students.

While the government can push reforms for formal TVET to implement and can create regulatory pressure for industry, the cause of promoting green jobs and green skills can be championed only by industry - mainly large corporations that have the ability to change to sustainable practices and to invest in green technologies. The initiatives undertaken by large businesses can create a ripple effect across smaller 
enterprises, businesses, and the informal sector, through their value chains, thereby triggering a more widespread demand for specific green skills.

\subsection{Summary of Main Findings}

\section{India has a Vibrant and a Stable Economy with a Labyrinth of Reform Policies and Programs}

India is one of the fastest growing economies in Asia, with a rising share in world GDP. The rate of GDP growth touched $9 \%$ in 2008, while the rest of the world was struggling with a financial crisis. India also presents a unique example in managing an enormous population of 1.2 billion people with large geographical, socioeconomic, and political diversity that is governed through a representative democracy consisting of federal, state, and local governments with differing political ideologies and policy emphases.

Stark inequities exist across the various states, economic sectors, demographic groups, and employment types in India. Some states are relatively wealthy and can be easily compared with fast-emerging economies of the world, and some regions are extremely poor and can be compared to Sub-Saharan Africa in Asia. Overall, living conditions are difficult for many individuals and families, with $33 \%$ of households with no electricity, $53 \%$ with no toilets on the premises, and $42 \%$ with no bathing facility.

Across the economic sectors, nearly $54 \%$ of the population of India is engaged in agriculture, which contributes less than 17\% to GDP. The manufacturing sector employs nearly $21 \%$ of the labor force but has a relatively low contribution to GDP of $18 \%$, whereas the services sector, which contributes over $65 \%$ to national GDP, employs just $25 \%$ of the labor force. Of a total labor force of 475 million, more than half $(55 \%)$ are illiterate. Ninety-two percent of the labor force are informally employed in the unorganized sector-in agriculture, building and construction, textiles, retail trades, logistics, and transportation - while less than 10\% (30 million) are estimated to be in the organized sector. Across demographic profiles, female literacy is $65 \%$ compared with $82 \%$ for males. Labor force participation of women came down from $36 \%$ in 1983 to $25 \%$ in 2011 . Women earn $62 \%$ of men's salaries for equal work. The majority of the labor force work under exploitative and vulnerable conditions, finding employment through informal means such as word-of-mouth references, and contractors. India ranks low (134th) on the Human Development Index (HDI) among 187 countries (UNDP 2011).

Policy measures in India to safeguard vulnerable situations and promote equity are elaborate and widely spread between the national and provincial legislative systems. The Unorganized Worker's Social Security Act, National Floor Level Minimum Wage, National Policy on Child Labour, and Contract Labour (Regulation and Abolition) Act are just some such measures. In addition, a number of employment generation programs, education schemes, and incentive systems aim 
to provide a just, humane, and equitable society. The Mahatma Gandhi National Rural Employment Guarantee Act, National Rural Livelihood Mission, and National Skill Development Policy are innovative schemes and policies to reform the old systems and to address chronic issues of low employability, poor productivity, and lack of opportunities.

\section{Environmental Policy Framework is Strong; Implementation is Weak}

Although India is one of the lowest GHG emitters per capita in the world, with its emissions being only one-quarter of the global average, as good global citizens the government has proactively developed a comprehensive policy, appropriate legislation, a regulatory framework, and programs for the promotion of energy efficiency, renewable energy, nuclear power, fuel switching, and energy pricing reform, to address GHG emissions. The National Action Plan for Climate Change, and its eight missions, outline multipronged, long term, and integrated strategies for achieving important, high-impact goals in energy efficiency, sustainable habitats, water conservation, and forest management. India has a dedicated Ministry for New and Renewable Energy and is one of the top 10 countries of the world in the production of renewable energy through wind, biomass, and solar means.

In addition, the National Urban Transport Policy spells out strategies designed to improve fuel efficiency, the use of cleaner fuels, and new forms of public transport. The Bureau of Energy Efficiency's labeling program for appliances, the solar lamp program, supercritical units in coal-based electricity production, and sustainable tourism certification match global standards in energy usage, energy conservation, and sustainable development. Regulations in the form of the Integrated Energy Policy of 2006 and the Energy Conservation Building Code mandate the green design of new, large commercial buildings, making energy audits compulsory in large energy-consuming units through a dedicated pool of "certified energy managers" who conduct environmental impact assessments, develop environmental management plans, and report annual energy consumption and energy conservation data.

While the policy frameworks attain global standards, this priority has not trickled down to grassroots implementation levels. The absence of implementation mechanisms and a lack of punitive measures encourage defaulters, and poor incentives dissuade enterprises from compliance.

\section{Skills Development Efforts are Diverse and Varied}

The TVET landscape has historically been diverse and complicated, with multiple agencies such as the Directorate General of Employment and Training, Ministry of Human Resource Development (MHRD), Ministry of Rural Development, and nearly 17 other ministries engaged in education, vocational training, technical training, and skills development. The launch of the National Skill Development Policy in 2009 led to the formation of the National Skill Development Corporation (NSDC) in 2009, the National Skill Development Agency (NSDA) in 2013, and the Ministry of Skill Development and Entrepreneurship in 2014. In addition, various industries and industry associations, NGOs, and the aid community have 
been independently working to achieve skills targets. The cumulative capacity of skills development, through all government programs, is about 10 million people per year against a target of 500 million by 2022 (Planning Commission 2011).

While the primary focus of policy makers and training providers is on basic provisioning and on ensuring that large numbers of beneficiaries get enrolled in skills development programs, the ability of certified graduates to do a job productively and remain employable remains questionable in the absence of quality benchmarks and an adequate control and coordinating mechanism. Further, the lack of linkages and pathways among primary, secondary, vocational skills, and higher education providers affects the motivation of the students and pushes vocational education toward a low status.

The absence of productive linkages between the education system and industry further poses problems with regard to retraining, which, in addition to having cost implications, also affects the productivity of industry and trade. Industry representatives during the ADB-EdUHK survey and interviews agreed that there is a large and burgeoning shortage of skilled workers. In the face of higher demand, coupled with poor training and accreditation mechanisms, the private sector has been increasingly forced to establish its own training and quality control mechanisms.

\subsection{Summary of Key Findings from the ADB-EdUHK Survey}

\section{Strong Regulation Both Deter as Well as Motivate Sustainable Practices}

The ADB-EdUHK survey and interviews refer to a number of findings that have implications for approaches used to address problems in education and training and their alignment with the issue of sustainable growth. For example, strict regulation does not necessarily result in compliance. Rising regulatory requirements have an impact on all industry sectors, and nearly half the companies surveyed believed that being strongly regulated through government interventions was both a deterrent as well as an opportunity to instill environmentally sustainable practices.

While at one level policy challenges exist, such as integrating economic, industrial, environmental, and skills development policies, at another level there are institutional bottlenecks to balancing multiple efforts, ranging from compliance-related matters to ensuring productivity enhancement, to saving costs, to managing innovations to be competitive, and to developing human capital.

\section{Rising Costs and Short-term Targets Push Environmental Management Low on the Priority List}

Short-term targets often overshadow long-term outcomes in both the government and the private sectors. Rising costs, increased competition, and poor profitability 
outweigh the efforts of technological innovations, skills development, and sustainable practices. While an institutional approach to sustainability is yet to evolve, individual motivation is high. Close to $80 \%$ of industry respondents witnessed a growing awareness among senior managers concerning climate change or environment-related jobs, while only $50 \%$ agreed to integrate jobs related to dealing with climate change into the work environment.

\section{Shortage of Skilled Workers is Impacting Businesses}

Nearly $60 \%$ of respondents from the energy sector confirmed that they are facing a shortage of skilled workers in energy-efficient construction and retrofitting, renewable energy, energy efficiency, and environmental services, thereby impeding the transition toward green growth. Rural electrification programs are suffering because of a lack of skilled workers. The reasons for these shortages include a scarcity of scientists and engineers, the poor reputation and limited attractiveness of certain sectors such as waste management, and the limited number of well-qualified and high-quality teachers and trainers in environmental services.

\section{Corporate and Social Responsibility Mandates and Import-Export Requirements are Key Drivers to Develop Green Jobs and Green Skills}

The hospitality industry appears to be most active in adopting sustainable practices in its businesses, whereas the transport and logistics sector leads in employing new workers for climate change. Corporate and social responsibility (CSR), import-export requirements, and government legislation seem to be the most important drivers for developing new green jobs and skills. While the demands for green skills in traditional industry arise mostly out of compliance with regulations, demands in new industries arise out of the resource crunch and global sustainability arrangements such as renewable energy. While the scope of green jobs may be limited, the scope of green skills in all jobs is unlimited. There is a greater emphasis on the requirements of hybrid skills (generic plus green) that top-up existing skills sets.

\section{Industry-TVET Linkages are Weak and Cosmetic}

The low levels of engagement between industry and TVET institutions continue to deter the improvement of courses and development of industry-relevant curricula. On average, only $18 \%$ of industry respondents provide course feedback to the TVET institutes, while TVET providers appear to be unsure about their programs with respect to green skills content. Green topics are largely excluded from the skills development curriculum. Only 50\% of TVET providers have "shades of green" content in their general curricula. Large numbers of nongovernment and private institutes seem to have created their own internal certification criteria, which may not be necessarily recognized by national and authorized bodies such as the National Council for Vocational Training or the All India Council of Technical Education. Most institutions in the survey indicated that their teachers are not adequately trained to provide green skills training to students. The absence of accreditation and certification on green standards is a deterrent. 


\section{Sector Issues}

Construction. Energy management and sustainable construction continue to be important concerns of the sector. Time and cost overruns are one of the major problems of the industry, triggered by a lack of formal training and inadequate systems related to skills assessment and the certification of construction workers. The construction sector is expected to employ about 92 million people by 2022 from the current 33 million.

Nearly $40 \%$ of respondents in the ADB-EdUHK survey agreed that they needed new workers for jobs and employment related to climate change; nearly $50 \%$ agreed to integrate jobs related to climate change in the work environment; and nearly $80 \%$ agreed that there is a growing awareness among senior managers about issues related to climate change. Nearly all respondents rated innovation in technology, products, processes, and services as important to be able to manage waste at construction sites and to improve energy efficiency. The change in work environments is leading to demands in generic and specific green skills.

Generic green skills (a foundation for all workers) required are awareness about environmental issues, energy and water efficiency, waste reduction and waste management, green procurement, understanding of standards and legislation, and the ability to implement them. Specific green skills required are in installing prefabricated components for green buildings, technical skills to promote heat and energy efficiency, energy-saving practices, and safety for firemen in brick kilns.

Energy. While the consumption side of the energy sector such as the labeling of equipment and appliances, energy efficiency in buildings, energy efficiency in industry, residential lighting, and agricultural pumping have identified roles and jobs that require green skills, the energy production side (largely coal-based) is yet to move to efficient technologies that can reduce emissions, and so the requirements of green jobs and skills are yet to be articulated. The renewable energy sector, on the other hand, does not identify green skills as an "add-on" in the industry, because they regard the sector itself as green and consider all jobs as green jobs. However, other problems are being faced by the renewable energy sector.

A Confederation of Indian Industry (CII) report (2010) identified that salary packages in the renewable energy industries are less when compared with other industries, and therefore attracting skilled labor is getting increasingly difficult. This was also observed in the ADB-EdUHK industry interviews, where graduates with renewable energy knowledge preferred IT jobs over positions in renewable energy because of the remuneration difference and relocation to less attractive locations.

While energy sector policies and strategic direction have sparks of excellence, the corresponding requirement for green skills is on the rise. Skills in project management, installation, commissioning, and grid integration of large-scale renewable energy projects, wind resource assessment, and technocommercial marketing skills are some of the skills increasingly required in wind energy. Some of the solar energy sector skills required are installing building integrated photovoltaics (BIPV) in buildings; project development skills in handling concentrated solar collectors (CSP); system integration in solar photovoltaics (PV); construction, 
installation, and commissioning of solar thermal systems; operation and maintenance skills in trouble shooting of circuitry of solar PV lanterns; and home lighting systems.

Apart from renewable energy, coal-based power generation requires skills in operating and managing supercritical units, ultra supercritical units, and underground coal gasification. Skills in carbon capture and storage, expansion of nonconventional gas resources like shale gas and coal bed methane, and coal washing are also required.

Transport. While Indian Railways is one of the largest employers in the world, having a separate ministry, roads continue to be the dominant mode of transport in India, carrying $85 \%$ of passenger and $60 \%$ of freight traffic, imposing a high cost on the economy by way of a much higher dependence on fossil fuels and high levels of GHG emissions.

While vehicular emissions standards get progressively tightened, compressed natural gas $(\mathrm{CNG})$ is rapidly being introduced for public transportation. Allied to the transport sector is the automobile and automotive component sector, which provides direct and indirect employment to more than 13 million people. Due to this rapid expansion and change in technologies, the transport sector, which currently employs nearly 7.3 million persons (more than $90 \%$ in roads and railways), may need 17.7 million employees by 2022 for roads, ports, railways, airports, and warehousing (NSDC 2009). In addition, the automotive industry may, directly and indirectly, employ 35 million by 2022 .

In addition to quantitative expansion, the industry is also experiencing qualitative changes. Nearly $80 \%$ of ADB-EdUHK survey respondents agreed that there have been job role changes including knowledge skills, technical skills, and attitude. The changes are demanding skills in different forms for lower as well as higher level operations. For example, rapid mass transport needs top-up skills in driving safety, communications, using complex machinery, and handling hazardous materials. Freight transport includes skills in materials handling equipment such as stackers, hydraulic or hand pallet trucks, forklift trucks, and jib cranes; handling of hazardous materials; and ability to handle increased tonnage and higher capacity trucks.

Services. Hospitality (travel and tourism) remains one of the largest service industries in India contributing 6\% to national GDP and 9\% to total employment. It is one of the priority sectors for the government and industry. The total number of jobs (direct and indirect) in the tourism sector in 2016 is estimated to be 77.5 million, up from 53 million in 2010.

The issue of environmental sustainability is actively being pursued by large and organized corporations; however, the same is yet to be percolated to small and medium-sized enterprises and the informal sector. While a number of standards and certifications such as Green Globe, ISO 14001, Earth Check, and Sustainable Tourism Eco-Certification are available for larger corporations, these are yet to be adopted by smaller enterprises.

Even though an increasing number of enterprises are adopting energy-efficient technologies, there are no specific requirements for specialized people for building 
a green environment in companies. The enterprises largely depend on top-up skills for existing staff. This was also seen in the ADB-EdUHK survey, where less than $50 \%$ of respondents expressed the view that a demand for green skills has impacted their business. The concern for increasing costs, changing consumer demand, and government legislation was much higher.

Some of the top-up green skills that the sector is actively seeking are recycling, reusing, and reducing fuel consumption in operations; disposing of nonbiodegradable garbage in a responsible way; procuring green materials; converting the use of polythene bags to paper bags and cloth bags; and using biodegradable cleaning chemicals. Some other emerging roles and green jobs in the sector are home stay owners and/or workers, golf caddies, polo grooms, nature guides, rural and water and hill adventure guides, security guards, tourist vehicle drivers, and masons for heritage constructions.

\subsection{Recommendations}

While the demand for green skills in all jobs is increasingly expressed by industry, not much interest is shown in differentiating between green and nongreen jobs. Though academic efforts may continue to identify green jobs across sectors, the industry sectors are more interested in introducing sustainable practices in production and services, which may have implications for creating new job roles that are green, or the requirement of top-up skills in the existing workforce. The evidence is clear that skills shortages are impeding the profitability, productivity, and competitiveness of enterprises.

Green skills development can happen at formal TVET institutions, through in-house skills upgrading, or as a response large societal movements, such as those lobbying about environmental improvement and sustainable development issues. However, each of these methods has limitations related to relevance, credibility, and cost-benefit that policy makers, industry leaders, and civil society organizations have to address in a coordinated way. For example, TVET cannot work in isolation, since it has to align with economic policies, climate change, and industry requirements.

\section{Integrate Skills Development Policies with Industrial, Economic, and Environment Policies}

While the National Skill Development Policy of 2009 is relatively new, the industrial policies and environmental policies have a legacy of their own and have evolved according to the socioeconomic and political realities of their formulation. Institutions have evolved around these policies over the years, and it is not an easy task to build consensus across policies and institutions to have a common approach with respect to green and inclusive growth.

An immediate assessment is required of the elements such as research skills in solar energy production under the National Solar Mission, and technical skills in 
recycling materials and urban waste management under the National Mission on Sustainable Habitat to determine the extent and nature of possible policy integration. The assessment may study important policies, programs, and institutions; explore areas of convergence and coordination; and provide the necessary thrust for green jobs and green skills development. Government, with the help of multilateral agencies, can bring in international expertise and good practices in order to learn the best ways and methods of policy rationalization and capacity development of institutions and individuals. Capacity development on processes and tools for green skills of institutions such as NSDA, NSDC, Aajeevika skills, the Capacity Building for Industrial Pollution Management Project, and the National Green Tribunal can also be organized under the leadership of the respective ministries.

The key responsibility lies with the Ministry of Skill Development and Entrepreneurship along with the Ministry of Environment and Forests and the Ministry of Commerce and Industry.

\section{Promote Green and Sustainable Practices as a Business Issue}

The pressure of achieving business targets, and stiff competition, push the issues of sustainability lower on the priority list, especially in small and medium-sized enterprises (SMEs) and in the informal sector. Businesses fail to realize that sustainable practices can solve problems of increasing costs, provide an edge over competition, and enable compliance with climate change mandates. Greening, therefore, should become a business issue and be championed by larger companies.

Large corporations such as Reliance Industries Limited and the Tata Group can help champion developing policy on green standards and sustainable practices. Green practice standards can also be included in the industrial policies of new economic corridors.

Further, they can communicate widely and strongly the benefits of adopting sustainable practices, and upskilling the existing workforce in SMEs through existing supply chains. Models of green innovation, as well as green skills development, may be rewarded and recognized through initiatives supported by CSR funds and also may be patented.

In addition, the larger corporations can also partner with leading higher education institutions in India as well as abroad through well-funded research projects on green technologies and practices that may need specific green skills.

The key responsibility rests with large corporations such as the Tata Group or Reliance Industries or with public sector corporations such as Indian Oil Corporation Ltd., Bharat Heavy Electricals Ltd., and Oil and Natural Gas Corporation along with $\mathrm{CII}$ and the Federation of Indian Chambers of Commerce and Industry (FICCI).

\section{Coordinate Action Between Foreign Aid and Investment Agencies}

The ILO Decent Work Team of South Asia can closely work with the World Bank's Vocational Training Improvement Project to bring elements of sustainable skills to TVET institutions. Similarly, the Department for International Development of the United Kingdom, UNDP, Japan International Cooperation 
Agency, GTZ, Australian Agency for International Development, and ADB can come together to develop a consolidated national strategy for support toward green growth, green jobs, and green skills.

Existing ADB support for strengthening skills development efforts in the states of Meghalaya, Kerala, and Odisha can have elements of green skills development. ADB technical assistance to NSDA can help focus the National Skills Qualifications Framework (NSQF) to build in components of green standards. ADB technical assistance to NSDC can help sector skill councils to develop green skills standards.

Documentation and dissemination of good practices (national and international) can be supported by aid agencies, while multinational companies (MNCs) may support models of innovation toward green practices and green education with private sector agencies and TVET institutions.

The key responsibility lies with aid agencies: ADB, World Bank, UN, MNCs through the CII, and FICCI.

\section{Initiate Easily Implementable Activities Around Green Skills}

Generic skills in training are easy to introduce and can have a progressive path to specific skills and courses. Content related to sustainable practices and climate change issues can be introduced into existing curricula, not only in TVET institutions but also through school education and higher education institutions. Major government-funded training schemes such as Aajeevika Skills (National Rural Livelihoods Mission) and the STAR scheme (NSDC) can include a number of "green" occupations in their training priorities.

Higher education institutions may also take the lead in the professional development of trainers through in-service training using special modules on green skills. The teacher training programs and courses can also start including generic and specific green skills modules. These can be included as accreditation requirements for training programs. MHRD may establish a green benchmark for teacher training programs.

The key responsibility is with the Ministry of Skill Development and Entrepreneurship (MOSDE) along with NSDA, NSDC, CII, and FICCI.

\section{Increase Coordination and Rationalization of the Private and Government Training System}

Training by the private sector cannot be ignored. While reforms in government TVET are being led by the line ministries, reforms in the private sector can be pushed through industry and employers. Parity in quality of training, incentives, governance systems, and industry relevance is required between the two. In addition, the state should create a framework to accredit and recognize the different forms of vocational training undertaken by different private industries.

While institutional initiatives are quicker to implement, large-scale reforms may also be initiated simultaneously. For example, MOSDE can develop green skills standards and dovetail them with the NSQF and National Occupational Standards (NOS). The NSDC may add "green skills" criteria in the validation process for NOS. 
Training providers can also be colocated with the industry to improve the relevance of training, improve teacher industry experience, offer research and development opportunities, create more responsive delivery arrangements, and foster industry skills development clusters.

The key responsibility is with MOSDE along with NSDA, NSDC, and large private sector corporations. Also to be engaged are the Ministry of Industry and Commerce; Ministry of Corporate Affairs; Ministry of Heavy Industry and Public Enterprises; and Ministry of Micro, Small and Medium Enterprises.

\section{Introduce Outcome-Based Incentives for SMEs and TVET Institutions}

In a scenario where there is great competition, it is unreasonable to expect that SMEs would be self-motivated to promote sustainable practices. India has an estimated 1 million such enterprises, and so reaching out to such a large number of organizations can be possible only from outcome-based incentives that could be direct, such as tax breaks; subsidies; viability gap funding; or indirect benefits such as awards and recognition, land provision, provision of training equipment, and international exposure visits. In addition, enterprises offering green skills development training should be entitled to general incentives concerning vocational training under government regulations or be allowed to recover training expenses through users or sponsoring institutions.

In parallel, TVET institutions that initiate programs or make special efforts for green skills development could be motivated through special entitlements, additional budgetary support, technical assistance, and/or international industrial exposure.

The key responsibility lies with the Ministry of Finance, along with the Ministry of Commerce and Industry, MOSDE, and Ministry of Labour and Employment.

\section{Promote Green Practices and Sensitivity Toward Sustainability as a Social Issue}

Green skills development should be understood not only as a matter of curriculum, and, in terms of content, limited to TVET institutions, but as something that should be built into a larger ecosystem of education, workplaces, social interactions, and political debates. In addition to formal TVET, sensitivity toward the environment should be developed through social interactions and public communications.

All forms of media-whether print, radio, television, or social - can be encouraged to position intelligent messages so that the community at large sees value in the importance of society moving toward greener practices, with green skills development becoming a necessity rather than an option. NGOs and self-help groups (SHGs) can be targeted with special green skills modules to reach out to involve women and marginalized groups, and to encourage them to develop green skills, which may or may not be employment-related skills.

The key responsibility will be with MOSDE along with CII, FICCI, the News Broadcasters Association, and the India Broadcasting Foundation. 


\section{Expand the Scope of Green Jobs and Green Skills to the Informal and Rural Sectors}

While most engagement between industry and the government with respect to sustainable growth is limited to the formal and organized sector and addresses mainly urban issues, research and policy must also generate evidence on the need for and situation of environmentally sustainable jobs and skills with respect to work in the informal economy such as small-scale manufacturing, trading, art and craftsmanship, and related to work in rural areas, especially agricultural processing and other nonfarm-related work.

The key responsibility lies with multilateral agencies such as ADB, the World Bank, and ILO along with research institutions and universities.

\section{Indonesia}

\subsection{Background and Overview}

In Indonesia the concept of greening is interpreted differently in the realm of TVET. While for some providers, greening is viewed as being a part of hygiene and safety, for others it relates to the introduction of a new curriculum relevant to international environmental standards, waste management, and pollution prevention, or else it has a broader interpretation that relates to climate change issues. The strongest point of agreement across all TVET providers concerns the need to develop a comprehensive approach toward adjusting TVET to meet the needs of a greening economy and the need to offer high-quality and relevant initial and continuing training programs to meet the demand for green skills. The fragmented understanding of the concept of greening is due mainly to the absence of a regulatory framework for green skills development in the country.

Industry is grappling with economic pressures and feels unable to address matters related to sustainable production; thus the need for specific activities concerning green skills is relatively low in industry's order of priority. However, there appears to be a contradiction, since at the same time industry has unequivocally stressed the need for generic green in all types of jobs. Generic green skills can be topped up, over the standard skills, and can be imparted either through TVET institutions (in the case of existing students) or through in-service training for members of the workforce through external experts or short-term development programs in TVET institutions. Such an approach could also be a revenuegenerating opportunity for the otherwise financially ailing TVET institutions.

TVET and the industries have created impressive "islands of excellence" that need to be mainstreamed. At the same time, the recently elected new government is currently positioning itself to prioritize its efforts toward giving a new direction to 
green growth with more integrated policies, leveraging upon the international expertise and the progressive work of past governments. Efforts in the past such as the "factory in schools" or "Esemka cars" "initiatives are to be popularized, and schools adopting such practices need to be incentivized. Similarly, Indonesia has a unique system where higher education is closely integrated with the vocational system, and such a link needs to be taken advantage of to develop high-quality trainers for the TVET system and to promote high-quality research in green practices.

Although green jobs are an emerging subject in Indonesia, the number of initiatives by the government, multilaterals, the private sector, and civil society in green jobs and green skills development are like scattered pearls that need to be beaded together. There are different "shades of green" in each of these initiatives, and some are very specific to a particular industry, geographical area, or situation; however, the real challenge is to bring out the principles behind these successes and to replicate them on a larger scale across industries and geographical regions. Large industrial corporations, together with international community support, can champion such efforts to make green practices a habit for individuals, businesses, TVET society, and society at large.

\subsection{Summary of Main Findings}

Indonesia is slowly recovering from a recent economic setback in 2013 when the local currency (the rupiah) suddenly fell nearly $20 \%$ against the US dollar. The GDP growth rate slowed from a peak of 7-5\%; and there was a spike in inflation, which rose to more than $8.5 \%$, from an earlier level of $4 \%$. Economists argue that the current economic crisis in the country may just be short term and will be corrected if restrictive policies on matters such as mining exports and foreign investment rules are revisited and made more progressive.

With a population of nearly 250 million (the fourth largest in the world), Indonesia achieved considerable economic progress after attaining democracy in 1999, through the progressive policies of the government and the optimistic mood of the people. Policies such as the Master Plan for Acceleration and Expansion of Indonesia Economic Development, which were implemented with a spirit of "not doing business as usual," not only contributed to economic progress but also had a positive impact on social indicators. Since then per capita GDP has increased fourfold, poverty has halved, literacy rates have reached an all-time high (95.8\%), and the HDI improved to 0.62 from 0.54 (a $15 \%$ rise) in just 10 years.

\footnotetext{
${ }^{1}$ Esemka cars (PT Solo Manufaktur Kreasi-SMK cars) are cars locally developed by senior high school students from several SMK schools (Sambijantoro 2015).
} 
Eighty-two percent of Indonesia's economic activity is concentrated in the western region of the country (Bali, Java, and Sumatra). Seventy percent of the population lives on the island of Java, which accounts for a mere $6 \%$ of the land area of the country. In recent years, several million migrants from other islands have moved to Jakarta and other major cities in search of employment but have found jobs mainly in low-end services, becoming part of a vast informal economy, which accounts for close to $70 \%$ of the GDP. They rarely earn the official minimum wage and receive few government benefits.

Existing education levels of the nearly 118 million labor force $(38 \%$ of whom are women) are worrying, with only $31 \%$ having attained secondary education. Almost half of the labor force $(48 \%)$ have not successfully completed primary education. Low levels of education, coupled with the informal nature of many areas of employment, result in a large portion of the workforce being vulnerable to exploitation and poverty.

\subsection{The Green Narrative-Dispersed and Disconnected}

The downside of the economic turnaround in Indonesia since achieving independence has been its adverse impact on the environment. Carbon dioxide $\left(\mathrm{CO}_{2}\right)$ emissions grew three-fold between 1999 and 2012. Furthermore, natural disasters have subjected the country's flora, fauna, and mineral resources to significant risks. Subsequently, the country has signed multiple international environmental protection agreements to protect biodiversity, lessen desertification, reduce ship and sea pollution, effect hazardous waste management, and promote marine life conservation. The National Council on Climate Change (NCCC), chaired by the president, is the main government body responsible for climate change policy coordination and development.

Several presidential regulations and laws, ranging from laws on the regulation of $\mathrm{CO}_{2}$ emissions, waste management, renewable energy, ecotourism, and community training on environmental sustainability in exploration, to the exploitation and rehabilitation of the environment have been passed, although large-scale implementation has yet to occur.

The concepts of green workplaces, green jobs, and green skills are somewhat new in Indonesia, and there is no proven set of methods, policies, or approaches to successfully implement green initiatives. However, organizations such as ILO have been providing technical assistance concerning green jobs in the tourism sector with active support from the Ministry of Manpower and Transmigration (MoMT), the Ministry of Tourism, and NCCC.

The private sector is also contributing to efforts toward green initiatives and practices. The Green Building Council of Indonesia has created GREENSHIP 
certification; Indecon (Indonesia Ecotourism Network) promotes and develops ecotourism in Indonesia; and garment factories are closely regulated by international consumer mandates.

\subsection{Education and Training: Awaiting Deeper Reforms but Making Efforts Toward Green Skills}

Unemployment among those who have attained secondary education (vocational) is nearly $12 \%$ compared with the country average of about $6.25 \%$. The government's policy push, and a budget allocation of almost $20 \%$ of GDP for education have not only helped expand the network of educational institutions across 6000 inhabited islands but have also improved the progression of cohorts. For example, those achieving lower secondary education went up from 31\% in 1994 to 52\% in 2013.

TVET is spread across three levels: secondary, postsecondary, and tertiary education. TVET depends more on private (nearly $73 \%$ ) rather than government institutions. The 16 university-level institutions that offer TVET teacher education plus the inclusion of vocational courses at the undergraduate and graduate levels have created a structure that is unique to the Indonesian education system.

Generally TVET is not as attractive an option as an academic pathway; however, expanding TVET at the higher education levels and the setting up of the NSQF are important breakthroughs in enhancing the image and attractiveness of TVET in Indonesia. The challenges of image concerning TVET in society and industrial communities have been improved over recent years due to committed intervention by the government, resulting in TVET being considered as a viable option for youth as an educational pathway.

The education system as a whole is making efforts to incorporate green content into training programs. Various organizations and ministries have piloted projects and initiatives to raise awareness and mainstream the green agenda. For example, senior secondary schools encourage students to green their campuses. The Ministry of Youth and Sports, together with the Central Bank of Indonesia, supports the "Indonesian green entrepreneurship program," which is aimed at increasing levels of entrepreneurship and the greening of businesses. The NCCC supports capacity building through a network of 19 universities, through courses aimed at lowering pollutant emissions. Similar pilot projects have been initiated by the Ministry of Education and Culture (MoEC) and the MoMT. The 2013 New Curriculum includes some green skills in the health and safety modules. For example, refrigerant recovery from air conditioners, and ways to process electronic waste are included as part of safety competencies; and energy saving and waste recycling are addressed in many major subjects. 


\title{
2.5 Summary of Key Findings from the ADB-EdUHK Survey
}

\author{
Industry Awareness About Green Skills is High for Internationally Linked \\ Companies
}

While the concept of green skills for all jobs is more widely understood than the concept for green jobs, companies that have strong international links tend to be the ones that most appreciate and want to implement sustainable practices. These companies also possess some form of international and national environmental accreditation, value customer demands and sensitivity to green issues, and encourage compliance across their supply chains. More than $50 \%$ of respondents in the construction sector, and over $40 \%$ of hospitality sector respondents agreed that a lack of skilled employees is proving to be detrimental to their businesses. However, fewer than $30 \%$ of respondents in all sectors agreed that they are currently employing new workers (or training workers) for green jobs.

\section{SMEs Have Less Motivation Toward Sustainable Practices}

Fewer than $30 \%$ of businesses across sectors, according to the ADB-EdUHK survey, use sustainable practices such as energy-efficient products and services, and recycling, in their work practices. Government legislation, increasing costs, and rising industry standards are more pressing issues affecting the businesses surveyed. However, more than $40 \%$ of the businesses surveyed in construction, hospitality, manufacturing, and energy expect high standards of sustainable processes and infrastructure across their supply chains.

\section{Engagement Between Industry and TVET Institutions is Low}

While a large number of industry respondents in the ADB-EdUHK survey agree on the importance of TVET work-based training of potential employees, the level of engagement between businesses and TVET institutions is reported to be low. Fewer than $40 \%$ of respondents expressed satisfaction with the outputs from TVET institutions.

\section{TVET Institutes Face Funding Constraints to Implement Green Skilling}

According to the ADB-EdUHK survey, more than $80 \%$ of vocational secondary schools (VSSs) and higher education vocational training providers (HE-VTPs) agreed that a transition to the greater use of products and services that comply with environmental regulations and standards is impacting changes in their programs and courses. Eighty-two percent of VSSs and 74\% of HE-VTPs recognize energy efficiency as a driver toward changing programs and courses. However, lack of funds is a constraint in implementing green training. A small number of partnerships with the private sector initially provided solutions, but these could not be sustained due to a lack of recurring funding. For example, Toyota installed oil recycling equipment at one VSS and conducted teacher training programs, but over 
time the equipment could not be maintained due to lack of funds, pushing the VSS back into using more traditional methods of teaching.

\section{Sector Issues}

Construction. According to a McKinsey report (see Mourshed et al. 2012), the construction sector in Indonesia will find it difficult to fill 40-50\% of positions requiring tertiary education and at the same time, it predicts an oversupply of TVET graduates working in the sector. More than $50 \%$ of respondents could not meet their sustainability goals due to lack of skilled workers in environment-related jobs. Growth in the construction sector in recent times, together with a rise in awareness about environmental processes and practices, has contributed to job changes, especially with regard to the knowledge, skills, and attitudes of workers. Nearly $73 \%$ of businesses in the construction sector identify the introduction of new standards related to sustainability or environmental issues as leading to new skills.

Green skills are increasingly required in impact assessments, innovative construction materials, and building techniques, and with regard to training in the correct use and application of materials and retrofitting. Some other areas of skills requirement are green certification, green construction techniques, and waste management at construction sites.

Energy. Indonesia is aiming to increase its renewable energy base to $26 \%$ by 2025 from the current level of $16 \%$. There is enormous pressure building on existing enterprises to increase their capacity and move toward greener practices. Nearly $75 \%$ of respondents in the ADB-EdUHK survey agreed that workloads were higher than usual and companies were not working to their full potential. In addition, government legislation such as PROPER is also creating pressures to incorporate new skills into work environments.

Skills are required not only at the operational level but also at higher levels, such as skills to assess business performance against the PROPER criteria, laboratory skills to monitor water and air quality, water and waste management, and stakeholder management. The demand for operational skills relates mostly to using vendor equipment, waste management, and top-up skills in installing energy-saving and alternative energy devices.

Transport. Transport contributes to nearly $13 \%$ of GHG emissions in Indonesia. In addition, nearly $51 \%$ of oil consumption in the country is attributed to the transport sector, while the number of vehicles is predicted to double by 2035. Road transport accounts for approximately $70 \%$ of freight movement and $82 \%$ of passenger movement. As a result, air quality has degraded to the extent that $60-80 \%$ of air pollutants in metropolitan cities are attributed to vehicular emissions.

While the government is taking active policy steps to address these problems, such as tax-exemption initiatives to encourage the production of low-cost green cars, and by mandating stricter emission norms, the sector needs urgent reforms that are implementable and also needs a sensitive and appropriately trained workforce to counter growing environmental concerns arising out of the sector. Some specific skills required in the sector include top-up skills in driving safety, communications, 
using complex machinery, and handling hazardous materials. Skills are required in materials handling equipment such as stackers, hydraulic or hand pallet trucks, forklift trucks, and jib cranes; dealing with hazardous materials; and an ability to accommodate increased tonnage and higher capacity trucks in freight transportation. Skills required in higher level jobs include understanding of fuel efficiency technology, carbon emissions, and sustainable urban transport planning.

Services. Indonesia is an attractive destination for tourists, with the hospitality industry growing at a rapid pace. The number of jobs in the sector was expected to reach 9 million by 2015, and the government plans to allocate $\$ 140$ billion for infrastructure development to support the projected expansion of the hospitality industry.

With nearly $60 \%$ of survey respondents agreeing that jobs in the industry will change due to a rise in sustainable practices, and more than $90 \%$ agreeing with the importance of environmental awareness in the sector, there is a corresponding requirement for skills in the areas of waste management, energy-efficient buildings and appliances, and the use of water. Some top-up green skills that the sector is actively seeking are recycling, procuring green materials, converting the use of polythene bags to paper and cloth bags, and using biodegradable cleaning chemicals.

Manufacturing. Manufacturing accounts for 25\% of Indonesia's GDP. According to a World Bank (2012) report, 84\% of employers in manufacturing have difficulty filling management positions, and $69 \%$ have problems sourcing other skilled workers. This is a serious issue that inhibits the further development and expansion of the sector. In addition, regulatory requirements and competitive and societal pressures are directing manufacturing industries to adopt greener and environmentally sustainable technologies and practices. Nearly $76 \%$ of respondents in the ADB-EdUHK survey identified job changes as being the most significant change related to greening their businesses, and 78\% agreed with the importance of TVET work-based training of potential employees.

Training is required in waste disposal and recycling, including knowledge of government regulations and related compliance. Skills gaps are reported in handling hazardous materials, LEAN manufacturing, and undertaking environmental impact assessments.

\subsection{Recommendations}

While the training providers integrate areas of green skills into their courses and curricula, the actual green practices required in agriculture, industry, and the services sector are quite different. The agriculture sector has connotations of "green" such as water conservation, the use of fertilizers, and appropriate cropping patterns, while the services sector is concerned more with conserving energy. The industry sector is interested in processes such as pollution control, recycling, waste management, procurement, and energy audits. The demand for green skills in traditional 
industries arises mostly out of the need to comply with regulations. Green skills demands in new industries such as renewable energy production arise out of a need to conserve resources and due to global sustainability agreements. Within the industry sector, there are different "shades of green" among the subsectors that need to be considered when developing strategies.

\section{Introduce a Paradigm Shift in the Skills Development System to Align with Economic and Environmental Policies}

While climate change commitments, laws on environmental protection, and compliance with emission standards take shape in Indonesia, the education and skills development system need a paradigm shift in order to align with the growing needs of industry for environmentally sustainable skills in every job role.

A closer assessment is needed to understand the elements of skills development policies and the scope for their alignment with the industrial, economic, and environmental policies of the country. Such an assessment may study important policies, programs, and institutions; explore areas of convergence and coordination; and provide the necessary thrust for green jobs and green skills development. The government, with the help of multilateral agencies, can bring in international expertise and good practices in order to learn the best ways and methods toward policy rationalization and the capacity development of both institutions and individuals.

The key responsibility rests with the National Board on Development Planning (BAPPENAS) along with MoEC.

\section{Design and Provide Outcome-Based Incentives for the Industry (Mainly SMEs and TVET Institutions)}

In a scenario of fierce competition and thin profit margins, it is not realistic to expect that industries, especially SMEs, will be self-motivated to promote sustainable practices. While the large industrial corporations have the ability to invest in sustainable practices and technology, the same is not true for smaller enterprises. Outcome-based incentives are therefore required to motivate SMEs to adopt greener practices. Incentives could be in the form of tax breaks; subsidies; viability gap funding; or indirect benefits such as awards and public recognition, land provision, provision of training equipment, and international exposure visits. In addition, enterprises offering green skills development training may be entitled to general incentives concerning vocational training under governmental regulations, or be allowed to recover training expenses through users or from sponsoring institutions.

In parallel, TVET institutions that initiate programs or make special efforts for green skills development could be motivated through special entitlements, additional budgetary support, technical assistance, and/or international industrial exposure.

The key responsibility is with the Ministry of Finance, along with the Ministry of Industry and Trade and MoEC. 


\section{Promote Sustainable Practices as a Business Issue}

The ADB-EdUHK study clearly shows that most businesses fail to realize that sustainable practices can solve the problems of increasing costs, developing a positive edge over competitors, and compliance with climate change mandates. Efforts to become green should become a business issue and move up to become higher on the priority list for action, even though the pressures to achieve business targets and to successfully meet stiff competition are high, especially in SMEs and in the informal sector. Larger companies can prove to be role models and become champions in advocating the benefits of adopting sustainable practices, and upskilling the existing workforce, through communication and regulation across existing supply chains.

The key responsibility lies with large corporations such as Astra International and the Lippo Group or public sector corporations such as Perusahaan Gas Negara, Perusahaan Listrik Negara, and Pertamina, along with the Indonesia Chamber of Commerce (KADIN).

\section{Push Green Growth, Green Jobs, and Green Skills Through Foreign Aid Agencies' Coordinated Action}

ILO is working with local communities on the Indonesian part of Kalimantan on a green jobs program called the "Green Livelihood Access for Central Kalimantan's Inclusive Environmental Response to Climate Change" that can access UNDP funds for energy conservation and environmental initiatives. There is the GIZ PAKLIM program to implement and disseminate climate mitigation and adaptation measures. Conservation International is working in the Sundaland areas, Wallacea areas, and the tropical wilderness areas of Irian Jaya in the hospitality and tourism sectors and can build synergy with the other international initiatives of $\mathrm{ADB}$ and the World Bank in the country.

Documentation and dissemination of good practices (national and international) can be supported by aid agencies, while MNCs may support models of innovation toward green practices and green education with private sector agencies and TVET institutions, respectively.

The key responsibility is with the aid agencies - ADB, ILO, GIZ, World Bankalong with KADIN and BAPPENAS.

\section{Introduce Generic Skills with Progressive Paths to Specific Skills into the Curriculum}

Generic skills in the standard curriculum of training are easy to introduce and may lead progressively to specific skills and certification. The introduction of such skills may be targeted through the full cohort of school education, technical education, and higher (university) education. Simultaneously, research in higher education institutions may be encouraged toward newer industry practices and technologies that are environmentally sustainable. Higher education institutions may also take the lead in the professional development of trainers through in-service training. 
While institutional-level initiatives are quicker to implement, large-scale reforms may also be initiated in the form of aligning the New Curriculum of 2013 (Government Regulation No. 70, 2013) and National Education Standards with the NSQF. Ways to include green skills standards in the Indonesian National Standards also need to be explored.

The key responsibility is with MoEC.

\section{Align and Rationalize the Standards and Outcomes between Large Private Training and the Government Systems}

Vocational training by large private sector institutions in Indonesia is very important and cannot be ignored. While reforms in the government TVET system are being led by the line ministries, reforms in the private sector can be pushed through by industry and employers. Parity in quality of training, incentives, governance systems, and industry relevance is required between the two. In addition, the state should create a framework to accredit and recognize the different forms of vocational training undertaken by private providers and industry.

The key responsibility lies with MOEC together with large private sector corporations.

\section{Promote Green Practices and Sensitivity Toward Sustainability as a Social Issue}

Green skills development should be understood not only as a matter that concerns the curriculum, and in terms of content limited to TVET institutions, but also as something that should be built into the larger ecosystem of education, workplaces, social interactions, and political debates. In addition to formal TVET, sensitivity toward the environment should be developed through fruitful social interaction and public communications.

All forms of media - print, radio, TV, and social — can be encouraged to position intelligent messages so that the community at large sees value in the importance of society moving toward greener practices, with green skills development becoming a necessity rather than an option. NGOs and SHGs can be targeted with special green skills modules to reach out to women and marginalized groups, and to encourage them to develop green skills.

The key responsibility is with MoEC along with KADIN and large media companies.

\section{Expand the Scope of Green Jobs and Green Skills to the Informal and Rural Sectors}

While most engagement with industry and government with respect to sustainable growth is limited to the formal and organized sector, and addresses mainly urban issues, research and policy also need to generate evidence on the needs and situation of environmentally sustainable jobs and skills with respect to work in the informal economy such as small-scale manufacturing, trading, and art and craftsmanship, related to work in rural areas, especially concerning agricultural processing and other nonfarm-related work. 
The key responsibility is with multilateral agencies such as ADB, World Bank, and ILO along with research institutions and universities.

\section{Sri Lanka}

\subsection{Background and Overview}

At the individual level in Sri Lanka the concept of "green jobs" and related "green skills" is understood mainly in terms of the importance of saving natural resources and not polluting the environment. In large industrial corporations, sensitivity toward "greening" is generally high because of a concern about rising costs. In the case of individuals in small, medium, and micro enterprises, although motivated, they do not generally find a platform, or an institutional mechanism, to translate their enthusiasm and understanding of sustainability into practice.

The importance of practices in support of sustainability in the government system is triggered by sensitivity toward the environment and global climate change agreements. Policies toward sustainable development are having a gradual impact on education and training. For example, TVET institutions have started including specific teaching and learning modules with respect to sustainability in their education programs, although in the absence of suitable standards and certification, appropriate knowledge and understanding are not operationalized at an institutional level.

Although there are islands of excellence in industry, education, and training following practices that demonstrate the adoption of green technologies, green jobs, and green skills, national consensus, strategy, and direction, are yet to evolve. While the government may push forward with reforms and the inclusion of green standards with a regulatory perspective, active interest of large corporations is important, since they can mobilize a countrywide movement to generate sustainable employment. The work of these corporations can also trickle down to small, medium, and micro enterprises. Also, the recent increase of financial and technical aid from foreign institutions (private, bilateral, and multilateral) also provides a positive environment that is conducive to introducing the notion of inclusive growth and the greening of the Sri Lankan economy as part of foreign aid and investment programs in the country.

While the Government of Sri Lanka may proactively lead such efforts, and direct education policy and institutions could start including generic and specific green skills in their programs and courses, active engagement of these institutes with industry is more critical to ensure continuous feedback on curriculum reform that is relevant to industry. While demand may not be imminent for such skills, requirements are going to rise in the medium and long term. Sri Lanka should be proactive to such future needs. 
Given the recent post-civil war development of Sri Lanka, which has seen the emergence of new, vibrant policies for economic growth, and the attracting of foreign aid and investment, the country is firmly on track to economic recovery. The impact of progressive and forward-looking policies generated by the government, the active participation of the international development community, and efforts toward achieving more social cohesion are all works-in-progress, and so the long-term impacts of such major initiatives are yet to be seen.

\subsection{Summary of Main Findings}

The Sri Lankan economy has achieved a rapid rate of growth over the past 5 years. During this period the country has been able to attract more foreign aid, private investment, and a $\$ 2.5$ billion loan from the International Monetary Fund (IMF). However, the benefits of this rapid development have not been spread uniformly across all regions. Imbalances are observed in certain areas such that the Northern Region, Uva, North Central, and Sabaragamuva have a much smaller share in the overall GDP compared with Western Province, which contributes up to $44.4 \%$ toward the national GDP. The country has one of the highest literacy rates (up to 90\% depending on which region of Sri Lanka) in Asia, which contributes to an increase in migratory workers and rising incomes. Nearly $61 \%$ of the population is below 34 years of age, and the dependency ratio is approximately $61 \%$, posing a big demographic opportunity for the country (Economic and Social Statistics of Sri Lanka 2013).

The Mahinda Chintana Vision Document 2010 of the Government of Sri Lanka envisions a transformation of the country into a strategically important economic center with a focus on human resource development and environmental protection. It estimates developing a manpower reserve of 350,000 skilled professionals. In addition, the Haritha (Green) Lanka Programme aims to mainstream environmental concerns into the national development planning process.

To stimulate greening of the economy, the Ministry of Environment (MOE) has established the National Green Reporting System with a view to promoting the reporting of sustainability performance in the manufacturing and services sectors. Various ministries have initiated programs related to environmental issues. Whether it is the Divi Neguma, a program for cottage industries; training the trainers programs by the Tertiary and Vocational Commission (TVEC) or by MOE; the setting up of institutions such as the Ceylon-German Technical Training Institute (CGTTI), supported by GTZ; or the Sri Lankan Institute of Advanced Technological Education under the Ministry of Higher Education, the intent of the government is progressive and reform oriented. Even international agencies such as ILO have initiated demonstration projects in Western Province in solid waste management.

The impact of progressive policies has resulted in the opening up of new employment opportunities that require specific technical knowledge and skills. 
About 50,000-70,000 skilled people are needed annually for large-scale development activities planned in the areas of naval, aviation, commercial, energy, road and transport, urban, and irrigation development. The industry sector requires nearly 500,000 skilled workers, while the services sector needs approximately 1 million skilled workers over the next 5-6 years. However, with limited institutions, the government estimates that only $30 \%$ of these requirements can be met with the existing training infrastructure.

There are approximately 1000 institutions under government and statutory boards, a large part of the training $(55 \%)$ being with the private sector and NGOs. While the government training landscape is divided among six primary agencies, policy formulation and planning, quality assurance, coordination, and the development of TVET are done by TVEC, which has developed 17 vocational education and training plans for key industry sectors and has established the Sector Policy Training Initiatives. If the curriculum goes beyond National Vocational Qualifications (NVQ) standards, other players such as Department of Technical Education and Training (DTET) develop the curriculum for general subjects, in consultation with industry. TVEC has also played a unifying role for all TVET efforts in the country and for achieving the broad goals stated in the national policies.

\subsection{Summary of Key Findings from the ADB-EdUHK Surveys and Interviews}

The ADB-EdUHK surveys and interviews captured the voices of important stakeholders from industry, TVET training providers, government, NGOs, and development agencies. A variety of issues were discussed ranging from the most effective ways to green the economy to the best ways for TVET providers to update their programs to become more relevant to meeting modern economic needs, including developing green skills for green jobs.

\section{Absence of Green Skills Affects Business}

Most respondents from the energy, construction, and transport sectors recognized the importance of green jobs and agreed that the absence of green skills is impacting their businesses. Though the response rate from the hospitality and apparel sectors was low on this issue, larger hotels reported that they had been able to mitigate the gap by providing in-house training. The same level of awareness and commitment to training was not evident in small and medium hotels. Transport companies reported a lack of green skills in many functional areas of their operations.

\section{National Policies Affect Businesses, but Rising Costs are a Major Deterrent}

While the transport sector is most affected by national policies, the construction and energy sectors are impacted by global environmental regulations and by pressure 
for developing sustainable infrastructure. The apparel sector is also guided largely by international mandates and policy guidelines. However, rising costs across sectors are putting pressure on businesses to adopt sustainable practices by using energy-efficient materials, though understanding about the use of sustainable infrastructure has been unusually low across sectors, indicating a poor understanding of the benefits and cost advantages of developing infrastructure that is environmentally friendly. This area needs significant capacity building across industry sectors.

\section{Downstream Supply Chains have Low Expectations, but Upstream Supply Chain have High Compliance}

Overall interest in the sustainability of the supply chain is generally low across sectors. Hospitality sector respondents indicated most interest, with $40 \%$ expecting suppliers to use sustainable infrastructure, largely influenced by supply chains in food and raw materials. The apparel sector, which maintains high upstream compliance for sustainable infrastructure, does not regard the same for the downstream supply chain. Fewer than $20 \%$ of respondents expected their supply chains to be energy efficient, to use sustainable infrastructure, or to use green products. Around $50 \%$ of respondents from the energy and transport sectors expected the supply chain to be energy efficient.

\section{Businesses Lack Engagement with TVET Institutions}

Representatives of all the business sectors reported that their engagement with TVET is low. Fifty-six percent of respondents from the energy sector and $40 \%$ of respondents from the hospitality sector indicated that they provided on-the-job training, whereas overall engagement with TVET remained weak. This low level of satisfaction has triggered major companies to develop their own training institutes.

\section{However, TVET Institutions Report High Engagement with Businesses}

However, the TVET sector provided a different response when asked about its engagement with industry. It is possible that the response of TVET institutions was based on industry-level interactions that are not necessarily within the same industry sectors covered in the ADB-EdUHK survey, and may include manufacturing or other sectors. National Apprenticeship and Industrial Training Authority (NAITA) institutions seemed to have the closest links with industry. For example, the Automobile Engineering Institute has links with more than 100 agencies and/or enterprises, such as Nissan and Mitsubishi, for workplace training. The NAITA institutions also reported having the most flexibility to adjust to industry needs and to bring about changes in curriculum. Although most TVET institutions agreed about having close linkages with industry, fewer than half of the Vocational Training Authority (VTA), DTET, NAITA, private, and NGO institutions reported being members of any industry group or an industry association. 


\section{Impact of Skills Development Policies High on TVET Institutions, with NAITA and UNIVOTEC Most Proactive}

Policies on skills development have a greater influence on TVET institutions than do economic or environment policies. The highest influence is on NAITA and DTET institutions. NAITA and the University of Vocational Technology are most proactive in terms of bringing about changes in their programs to manage transitions toward a green economy.

\section{Formal Demand for Green Skills from Employers is Absent}

TVET providers believe that although employers do not require green skills, vocational training providers (VTPs) have difficulties in addressing the development of green skills. Fewer than $40 \%$ of VTAs and around $20 \%$ of DTET institutions, other ministries, private providers, and NGOs believe they need to develop comprehensive approaches toward greening of their programs. Due to the emerging nature of the subject of green jobs, and a lack of any specific policy or curriculum on green skills, institutions are integrating green skills with existing training courses and programs. Most training providers remain uncertain about the issue of green standards. Further, due to a lack of internal capacity and limited professional development of teachers in the area of green skills, the institutes depend largely on external collaboration and experts.

\section{Sector Issues}

Construction. Sri Lanka has an estimated 300,000 skilled construction workers, with fewer than $5 \%$ of them formally trained and certified for green skills. However, due to the fast growth of the sector, it is estimated that another million workers would be required (ICRA 2011: 16). The emergence of the Green Environmental Rating System for buildings and other environmental and regulatory conditions is leading to changes in job roles, especially with regard to knowledge, skills, and attitudes, and also to changes in processes and work systems. For example, lack of knowledge and skills, and prevailing attitudes lead to wastage of raw materials Proper training in this area could lead to significant savings of $\mathrm{CO}_{2}$ emissions.

Although companies have been hiring university graduates and TVET trainees, it is significant that only $25 \%$ of construction sector respondents in the ADB-EdUHK survey believed that TVET institutions are able to meet industry requirements. Larger construction companies recognize the importance of TVET and suggest that TVET providers should arrange industrial placements for training in safety and environmental skills and to develop quality assurance awareness.

During the interviews, shortages of construction professionals such as service engineers; quantity surveyors; project managers; construction managers; and other technically skilled jobs such as electricians, plumbers, masons, and fabricators were consistently reported. Respondents also suggested the need for upgrading skills concerning new technologies. Other areas suggested for skills enhancement were training in the correct application of cement, plaster, and other surfaces to reduce 
waste and poor finishes, top-up training in new building technologies, and effective recycling on sites.

Energy. Growth in energy, especially in renewable energy, is expected to generate high levels of employment requiring green skills. The government has set a target of generating $20 \%$ of electricity through renewable sources by 2020 , mainly wind, as there are strong monsoon corridors in the country. As a consequence, the demand for training is increasing with regard to the manufacturing of small turbines, and assembly and installation of large turbines and high-voltage connections to the grid. Solar energy skills are needed in various areas such as installation and maintenance, though the sector is still emerging.

Fifty-six percent of respondents in the ADB-EdUHK study agreed that changes in processes in their companies have occurred due to a "greening" of the business. Changes in job roles and work processes are also triggering a demand for newer skills. Only $33 \%$ of respondents in the energy sector agreed that TVET institutions have the ability to provide for industry requirements. Large companies in the sector commented that TVET graduates lack practical knowledge and that their courses are out of date.

The businesses are in favor of increasing informal and on-the-job training in the areas of installation and maintenance skills for wind turbines and the installation of solar panels for domestic use. At a higher skills level, energy companies require sustainable product development specialists, environmental managers to oversee project site development, International Organization for Standardization (ISO) auditors, and site environmental officers to maintain standards and compliance.

Transport. The dominance of road transport (nearly 93\%) has given rise to issues related to freight and passenger transportation, fuel efficiency, and maintenance of vehicles. Railways, air transport, and sea transport have initiatives around waste disposal, energy efficiency, and green buildings leading to requirements in green skills but the scale of road transport and its related greening requirements need more attention.

Only one-third of transport companies agreed that they had brought about changes related to work systems to promote the greening of their businesses, and a smaller number had made changes in job roles, processes, or value chain requirements. Changes in work systems center primarily on the challenges of fuel efficiency, including the deployment of new technology for further fuel efficiency, pollution control, and alternative fuel options. Job changes are related to the introduction of liquid waste recycling, the removal of solid waste, and the separation and recycling of parts and components.

Respondents from the transport sector identified the need for solid and liquid waste management and disposal, particularly relating to spillages. The transport sector as a whole identified a shortage of environment managers, energy managers, managers for aviation fuel, and supervisors of aviation fuel management and flight operations. Understanding the safe usage of chemicals to comply with Registration, 
Evaluation, Authorisation, and Restriction of Chemicals standards was another area identified as important.

Services. Though hospitality and tourism have been growing, there is a massive shortfall of services and facilities compared with the increasing number of tourists. Due to changing customer demand and international regulatory requirements for energy efficiency, almost $60 \%$ of enterprises in the ADB-EdUHK survey had experienced a change in work systems, while $50 \%$ had introduced changes in job roles. Some of the triggers for these changes were practices regarding conserving water, wastewater disposal, and conserving resources during delivery and transport.

However, sector employers continue to be concerned about the poor attitude of TVET graduates. Only $20 \%$ of respondents agreed that TVET institutions were meeting industry requirements. Respondents surveyed from large business enterprises identified the poor quality of work performed and recommended greater emphasis on soft skills, foreign language competencies, and personality development. They also believed that TVET graduates are better suited for operational level employment than managerial roles. While quality continues to be a serious issue, the output capacity in the country is also low. Against an anticipated requirement of 9000 employees per year, the country produces only 1500 graduates every year (Sri Lanka Tourism sector summary by Capital Alliance).

Large hotels require specific policies and practices to address sustainability and compliance, requiring knowledge of energy-saving working methods to reduce the carbon footprint, and skills to implement and/or maintain ISO certifications. In rural areas, hotels need skills to work closely and effectively with local communities to develop the means for promoting and sustaining local livelihoods. They also require green procurement skills, and cultural and environmental protection knowledge.

Manufacturing. Textile and apparel account for nearly one-third of employment in manufacturing, and nearly $65 \%$ of the workforce is reported to be skilled. The manufacturing sector as a whole accounts for about $52 \%$ of total exports from the country. Environmental issues are given importance, and women are employed at all levels in the industry. The textile and apparel sector provides the best employment opportunities in the entire country for women. Rural women prefer this sector, as it provides employment at their doorstep.

Nearly $50 \%$ of apparel industry respondents agreed they experience changes in work systems due to the greening of their businesses. Some of these changes may be triggered due to the "Garments without Guilt" initiative launched by Sri Lanka's apparel sector to focus on ethical manufacturing and sustainable development.

As the industry expands and job roles change, dependence on TVET institutions grows greatly. Large companies recruit graduates from institutions such as the CGTTI but have in-house training systems, such as the Hirdaramani Group or Brandix Eco-centre, training and mentoring in the areas of energy consumption, water consumption, and waste generation. SMEs generally recruit from technical colleges, and microenterprises prefer to train informally through on-the-job training. The industry also depends highly on trained women from local villages. 


\subsection{Recommendations}

With the changing needs of industry where jobs are becoming more modular in nature, the training for such jobs also needs to become nonlinear or modular. Multidimensional skills, especially greening skills, help in reducing the cost of production, improving productivity, and maintaining high standards with respect to sustainable practices. Policy makers and practitioners have a major task to balance emerging needs and priorities with existing implementation frameworks.

\section{Align Education and Environment Policies}

The Government of Sri Lanka's commitment toward green growth is evident through various policy documents, especially the Mahinda Chintana Vision-2010. However, the lack of an adequate and competent workforce with appropriate skills remains a bottleneck. There is an urgent need to revisit standard approaches to addressing issues within education and training, and to align these with sustainable growth. Ensuring a transition toward green growth, with adequately trained human capital, is not easy to achieve. While the vision document is a first step to achieving a paradigm shift toward green skills, achieving consensus; coordinating among political, social, and industrial leadership groups; and aligning economic, industrial, environment, education, and skills development policies are important areas to be addressed. This requires bringing in international expertise and good practices to learn the best ways and methods of policy rationalization, and the subsequent capacity development of institutions and individuals concerning processes and tools to sustain the policy paradigm.

The key responsibility lies with the Ministry of Youth Affairs and Skills Development in close collaboration with Ministry of Industry and Commerce (MOIC), Ministry of Economic Development, and MOE.

\section{Provide Incentives to Promote Green Skills}

Incentives for the private sector and TVET institutions are important to motivate them to move toward green skills development. Enterprises offering green skills development training should be entitled to general incentives concerning vocational training under governmental regulations or be allowed to recover training expenses through users or sponsoring institutions. The government may encourage financial incentives (tax breaks) to promote green industries, which can subsequently generate green jobs and a need for green skills. The government may also provide incentives in the form of land provision, tax breaks, and the provision of training equipment to enterprises promoting green skills.

The key responsibility is with the Ministry of Finance and Planning along with MOIC.

\section{Promote Greening as a Business Issue}

Green skills is not a priority for business operations, because the pressure of achieving business targets, and stiff competition, push the issues of sustainability 
low on the list. It, therefore, becomes very important that greening should become a business issue, which can be championed by larger companies. The benefits of upskilling the existing workforce need to be communicated widely in the SME sector.

The key responsibility rests with large corporations such as the HOLCIM Group, Aitken Spence, Haleys, and Sri Lanka Telecom, or public sector corporations such as the Ceylon Petroleum Corporation and Sri Lanka Ports Authority.

\section{Promote Green Line of Credits from Foreign Aid and Investments}

There are large foreign investments by multinational corporations, IMF, and others in Sri Lanka. ILO has initiated training programs for VTPs, GTZ is leading vocational training programs in northern Sri Lanka, and ADB has a Skills Sector Development Program. The agencies need more coordinated action to instill the importance of transition toward sustainable practices and requirements for green skills development.

Aid agencies may promote documentation and dissemination of good practices (national and international) and also support models of innovation toward green practices and green education with private sector agencies and TVET institutions, respectively.

The key responsibility is with the aid agencies like ADB, the World Bank, and the UN, and with multinational corporations.

\section{Include Green Skills as Part of Curricula in All Levels of Education}

Knowledge about green skills need to be introduced into the existing curricula, not only in TVET institutions but also in schools and higher education institutions. Generic skills in training can have a progressive path to specific skills and courses. Research in higher education, therefore, becomes critical to develop newer practices and technologies that are environmentally sustainable. Higher education institutions may also take the lead in the professional development of trainers through in-service training.

While institutional initiatives are quicker to implement, large-scale reform such as alignment among NVQ levels and National Competency Standards is also required in parallel.

The key responsibility is with TVEC along with NAITA and public and private TVET institutions.

\section{Rationalize Private and Government Training Systems}

The state should create a framework to accredit and recognize the different forms of vocational training undertaken by different enterprises. Training in the private sector needs to be integrated with the formal TVET system. Together with efforts to strengthen the formal TVET system, policy makers should not ignore the existing private sector training system and should take appropriate steps to achieve parity of reforms in the two systems. Teachers working in private sector vocational training establishments (with the same competencies and capabilities) should enjoy the same incentives as teachers in government vocational training institutes. 
The key responsibility lies with TVEC along with NAITA, DTET, the University of Vocational Technology, and private TVET institutions.

\section{Involve Media}

In addition to formal TVET, sensitivity toward the environment is often developed through social interaction and public communications. Green skills development should be understood not only as a matter of curriculum, and in terms of content, limited to TVET institutions, but as something that should be built into a larger ecosystem of education, workplaces, social interaction, and political debates.

All forms of media - print, radio, television, and social — can be encouraged to position messages so that the public sees the importance of society moving toward greener practices - with green skills development becoming a necessity rather than an option. NGOs and SHGs can be targeted with special green skills modules to reach out to the community and to involve women and marginalized groups, to encourage them to develop green skills. These may or may not be employmentrelated skills.

The key responsibility lies with TVEC and the National Environmental Protection Council (NEPC), along with media companies and NGOs.

\section{Expand the Scope of Green Jobs and Green Skills to the Informal and the Rural Sectors}

Most industry and government engagement with respect to sustainable growth is limited to the formal and organized sector, and address mainly urban issues. Research and policy also need to generate evidence of the needs and situations of environmentally sustainable jobs and skills in the informal economy such as small-scale manufacturing, trading, art, and craftsmanship, etc., and related to work in the rural areas, especially agricultural processing and other nonfarm-related work.

The key responsibility is with multilateral agencies such as ADB, World Bank, and ILO along with research institutions and universities.

\section{Viet Nam}

\subsection{Background and Overview}

Viet Nam is one of the few countries proactively taking initiatives toward green growth, green jobs, and green skills. While the United Nations Industrial Development Organization (UNIDO) together with Ministry of Industry and Trade (MoIT) developed a "Green Industry" strategy for sustainable industrial development, GTZ together with the General Department of Vocational Training (GDVT) has developed a TVET reform project at GDVT, with a special focus on greening.

While government action may be triggered by global mandates and agreements, the industry motivation in Viet Nam is quite fragmented and lacks a unified 
approach, mainly because of the large number of SMEs. Also, the different growth trajectories of each industry sector impede concerted effort toward sustainable practices. Environmental issues, therefore, move low on the priority list of some of these sectors. Large corporations, on the other hand, are highly sensitive to the importance of sustainable practices and invest in technology and human skills as they realize their positive impacts on cost saving, brand goodwill, and edge over competition.

Even though policy and practice are gradually converging and there are examples in Viet Nam that demonstrate the power of going green, a larger society-wide impetus is still required to demonstrate the advantage of skills that are sustainable, employable, and remunerative over standard skills. The government may create incentive systems, exert regulatory pressures, and push reforms, but the real indicator of the country acknowledging green practices would be evident once small and medium industries start recognizing the value of green skills.

Government TVET institutions can easily start green skills courses through policy measures; however, absorbing those skills and providing better compensation in industry will remain a bigger challenge. While success can be achieved in organized businesses, the larger challenge would be small and microenterprises and the informal sector, which have significant shares in the overall employment market. The private TVET sector could easily align its courses toward green skills development when there is a demand from the industry as a whole.

While green jobs may have different shades of green across sectors - more in agriculture, less in traditional energy production, more in renewable energy production, and even less in industrial manufacturing - generic green skills development across all jobs is relatively easier to identify and implement. These skills may lead to specific and more technical green skills in the future. The country's leadership across government, the corporate sector, and civil society need to initiate steps toward generic green skills not only through formal education and training but through a larger social interaction embedded in workplaces, social discourses, and political debates.

\subsection{Summary of Main Findings}

\section{Viet Nam Rises After a Difficult Past}

Viet Nam is a prominent developing economy in Asia and is expected to become the world's 17th strongest economy by 2025. To reach its current level the country has over the years navigated important potential obstacles such as colonization, war, central planning, and a closed economy. It is a growing and dynamic economy that is set to achieve important economic reforms and poverty reduction goals. It has also made considerable progress in economic, social, and environmental aspects of sustainable development.

Viet Nam's progress has been augmented in recent times by the government's double agenda of restructuring state-owned enterprises and developing the labor 
market. From 2000 to 2013, Viet Nam's GDP growth averaged 6\%, reaching an all-time high of almost 9\% in December 2007 and a record low of 3\% in March 2009. During 2000-2011, Viet Nam achieved significant improvements in human capital development owing to high economic growth. Manufacturing, IT, and various high-tech industries account for the largest share of the economy. In addition, oil production and tourism are also dominant industries.

The literacy rate of Viet Nam is a high $94 \%$, which has contributed much to the country's economic growth. However, the required level of skills in the country is relatively low, with less than $4 \%$ of the labor force having any vocational training. Nearly $85 \%$ continue to work without formal training or qualifications. As a result, many become self-employed or engage in household work. Both education and employment reflect a lack of gender equity and pose a demographic challenge, since nearly one-third of the population is below 24 years of age.

\section{Green Growth is High on the National Agenda}

The Viet Nam National Green Growth Strategy of 2012 seeks to promote "green thinking" by aiming to reduce GHG emissions; increase clean and renewable energy; and promote the greening of production, lifestyles, and consumption. In addition, Viet Nam's progressive policies on climate change have been put in place to strengthen the capacity of society to cope with climate change.

In addition, the government has collaborated with many other countries for official development assistance projects, e.g., with Germany, Japan, and Luxembourg. The government has also linked up with various international organizations to facilitate the planning and implementation of various greening initiatives, such as GTZ, ILO, the Food and Agriculture Organization of the United Nations, UNIDO, the British Council, and the World Bank. The government has partnered with the EU to study consumer behavior, motivation, and challenges toward sustainable consumption. The government is also developing a methodology and tool kits for Get Green Viet Nam, a program to increase the share of sustainable consumption by Vietnamese consumers and increase the capacity of consumer organizations and government for convincing and supporting consumers in choosing more sustainable consumption behavior. Many NGOs have also initiated greening measures in the country, including the Viet Nam Cleaner Production Centre, Viet Nam Business Council for Sustainable Development (VBCSD), Viet Nam Vocational and Training Association, and Viet Nam Environmental Industry Association (VEIA).

\section{Education and Skills Development Need to Speed up to Match Economic Growth}

The Strategy of Education Development 2011-2020 and The Strategy of Vocational Training Development 2011-2020 both emphasize that vocational training is the joint responsibility of the state and the private sector. Quality accreditation for vocational training has been officially defined in the Law on Vocational Training 2006, and accreditation activities commenced in 2008. The new Education and TVET Acts of 2005 and 2006, respectively, provide a higher degree of autonomy to TVET institutions in enrollment, recruitment, program planning, and financial 
management, and lesser control over assessment and certification processes. This flexibility encourages TVET providers to review their courses and to communicate with industry, seeking feedback that could be used to adapt training to employers' needs. However, even though the system has empowered TVET providers, many of them are still not able to do enough due to lack of funding and technical resources to renew machinery and equipment, improve curricula, and establish industry linkages.

Further, coordination problems between the Ministry of Labour, Invalids and Social Affairs (MOLISA) and the Ministry of Education and Training (MOET), and implementation hurdles at the provincial level have led to a lack of convergence at the TVET institution level and have affected the quality and consistency of TVET programs. Many TVET graduates remain unemployed, indicating a mismatch between skills taught and skills required for employment.

While at one end of the system, the government is introducing initiatives to mainstream vocational education and remove the stigma of low status associated with TVET, at the other end the system grapples with governance issues. For example, the introduction of 2-3 years of professional secondary and technical education (under MOET), and 1-3 year vocational training programs for students who have graduated from lower or upper secondary education, toward a vocational intermediate certificate or collegial diploma (under MOLISA), are encouraging steps; but the poor quality of teachers, faculty, and instructors, and the low industry relevance of traditional vocational courses, remain critical issues.

\subsection{Key Findings from the ADB-EdUHK Survey and Interviews}

Since 1986, Viet Nam has undergone economic reforms and changes that have transformed the country from being a centrally planned to a market-based socialist economy. In addition, Viet Nam's decision to join the World Trade Organization has significantly shaped its industrial structure and has paved the way for trade partnerships with strategic partners, such as the US, EU, and Japan. The Enterprise Laws of 2000 and 2005, which aim at providing a level playing field for all enterprises regardless of ownership status, have also contributed to the progress and the development of a positive industrial and trade environment in the country. The government intends to implement an industrial policy for sustaining growth in various sectors such as agro-industry, food, machinery, mechanical engineering, and construction materials; and by developing key industries such as energy, chemicals, metallurgy, and mechanical engineering.

\section{Adopting Sustainable Practices can Control Increasing Costs}

The demand for green skills in Viet Nam is increasing in the five high-growth sectors of construction, transport, energy, hospitality and tourism, and manufacturing. The highest demand is in hospitality and tourism, followed by the 
manufacturing sector. There is a strong realization among industries that the best way to manage increasing costs is to adopt sustainable practices; however, adopting sustainable practices adds to increasing costs. Companies, therefore, need to manage the matters of meeting customer demands for green products and introducing green processes, technology, and skills. Many of the green skills demands in hospitality and manufacturing arise out of the need for impact assessments. The enterprises also expect high sustainability standards from their supply chain.

\section{Regulatory Pressure and Competition are Driving the Demand for Green Jobs and Green Skills}

Unlike other countries, industry in Viet Nam is driven actively by the skills development policies of the government, in addition to environment policies and economic policies. The energy sector has reported the maximum influence of skills development policies on the sector, and hospitality companies reported higher influence of economic policies than skills development policies. Competitive pressures are also affecting the transport and manufacturing sectors and are gradually triggering a demand for environmentally sustainable practices.

\section{Industry and TVET Linkages are Poor}

About $70 \%$ of all businesses view TVET training of potential employees as important, but only $10 \%$ of businesses actively engage and dialogue with training institutes. TVET providers are also very much aware of the changing scenario where the economy is going green and so have introduced new and relevant courses in their curricula, particularly in the last 2 years. However, in the absence of appropriate greening standards and certifications, the accreditation of such programs becomes difficult. In addition, a lack of practical experience and low pedagogical ability among teachers and trainers in green skills creates bottlenecks in implementation. Vocational secondary schools (VSSs) and vocational training centers (VTCs) are actively involved in staff development and the training of trainers.

\section{Sector Issues}

Construction. Construction for housing, transportation, energy, water supply, drainage, and waste disposal is an integral part of the National Strategy for Green Growth for 2011-2020 and documents released for Vision to 2050. The policy emphasizes construction in urban centers above Grade II standards.

The changing preferences of domestic consumers for green buildings are putting pressure on developers and construction companies to develop low cost, sustainable infrastructure options for consumers. Even though more than $50 \%$ of businesses agreed to introduce resource-saving measures in electricity consumption and water use, and there is a rising demand for green skills, the lack of availability of such skills has not greatly affected business. Lack of green skills has impacted only $23 \%$ of businesses, and only $18 \%$ believe their growth was restricted due to an absence of such skills.

Some of the skills articulated by industry concern the designing of green buildings, waste management, and pollution control. Demand is increasing for skills 
in reducing topsoil damage, building retaining walls for roads and bridges that can withstand flooding, installing sensors for cooling and heating, and energy-efficient ventilation systems.

Transport. Road construction and rehabilitation have been the main focus of most transport policies in Viet Nam in recent years. Rising levels of motor vehicle use, urbanization of road space, air pollution, urban congestion, and exposure to major flooding and storm damage have impacted the environment adversely, and therefore new regulations like high vehicle tax, transport planning compliance with environmental protection standards, and emission and noise standards have been put in place.

A large number of respondents from the transport sector did not see much impact of social demand (less than 10\%), or a need for impact assessments (only 25\%), leading to a requirement for green skills; however, emission norms, and a knowledge of environmentally friendly engines, are more likely drivers for this demand.

While active steps have been taken to train the large workforce expected in the sector $(630,000$ by 2020$)$, only $30-35 \%$ are expected to receive training in the interim. This is due largely to a shortage of infrastructure and an absence of structured programs for the mostly unorganized transport sector.

The skills required for higher level jobs include understanding of a higher level knowledge of fuel-efficient technologies and carbon emission; and sustainable urban transport planning skills to balance the transport system among rail freight, air, sea, and road transport. The medium- to low-level jobs require skills in the repair, operation, and maintenance of energy-efficient engines.

Energy. To ensure energy security against growing demand, the country strategy is targeted toward enhancing national capacity in research and the development of technology to use clean and renewable energy, increasing international involvement in developing and using clean and renewable energy, and increasing clean and renewable energy ratios with respect to total national energy use to protect natural resources and minimize GHG emissions.

The sector is witnessing rapid changes with respect to new work systems, including job role changes specific to attitudes, technical knowledge, and specialized skills. The pressure for sustainable practices in the downstream supply chain is also high. Almost $80 \%$ of respondents agreed to the importance of energy efficiency requirements, and sustainable consumption and production processes from downstream supply chains.

Higher level skills are required in waste management and treatment, containment of site pollutants, environmental risk management, and determining costs and skills in replacing obsolete technologies. Skills are also required in collecting data to provide accurate measures, and for communicating and reporting to meet environmental standards. Lower level skills are needed in operation and maintenance, pollution control, and waste management.

Services. Nearly 870,000 workers will be required in the tourism sector by 2020 , of whom the trained resources are expected to be about 58\%, with $33 \%$ having higher education qualifications. Rising CSR and the introduction of international or 
national standards such as Green Globe or Green Lotus are having an impact on the requirement for new skills in the sector. Most businesses believe that green skills development can be channeled through TVET institutions, since the demand is far greater than the supply. With more and more businesses adopting green practices in electricity consumption, water use, and recycling, the requirement for green skilled labor cannot be developed exclusively in-house or through on-the-job training programs.

An understanding of international standards such as Green Globe and the national Green Lotus, energy auditing, natural sciences for guides taking tourists around environmentally sensitive areas, maintaining and troubleshooting alternative energy supplies and grey water systems, maintaining solar panels, conversion of furnaces to biofuels, and maintenance of waste and sewage treatment facilities are some of the emerging skills across the spectrum of higher to lower order skills.

Manufacturing. Textiles, readymade clothes, leather, chemicals, agroprocessing, electrical, electronics, motor vehicles, and automotive parts are strong subsectors of the manufacturing sector that are experiencing rapid advancements in technology, competition, global trade, and skilled workers.

Skills gaps at higher job levels are reported in the design and monitoring of solid and hazardous waste management and the management of contaminated sites, lean manufacturing, ${ }^{2}$ and environmental impact assessment. Skills gaps are also reported at medium and lower levels, especially in water treatment and handling hazardous materials.

\subsection{Recommendations}

Evidence shows that skills shortages may be impeding the transition to green growth in Viet Nam. Demand from the industry sector for jobs that are both environmentally sustainable and decent is on the rise. Initiatives that heighten awareness of sustainable practices and green employment should be developed. But TVET cannot work in isolation. TVET needs to align with economic policies and new climate change and industry requirements. There is an urgent need to revisit standard approaches to addressing issues within education and training, and to align these with sustainable growth. But ensuring transition toward green growth, with adequately trained human capital, is not easy to achieve in reality.

\section{Closely Align Education, Economic, and Environment Policies}

Consensus and coordination among political, social, and industrial leadership groups is evident through the National Green Growth Strategy 2012. However,

\footnotetext{
${ }^{2}$ Lean manufacturing (or lean operations) is a strategy for business improvement by producing better products and/or better services by using fewer resources. "Doing more with less and doing it better." (Goetsch and Davis 2009, pg. 508).
} 
alignment among economic, industrial, environment, education, and skills development policies is still difficult to achieve.

Fortunately, there is no lack of knowledge about the subject. Knowledge from within and from other countries, and partnerships with international agencies are available to bring in new perspectives, new models, innovative practices, flexible funding, and high-quality research to develop individual and institutional capacities to deliver large-scale programs around green economy, green jobs, and green skills.

Government, with the assistance of multilateral agencies, can bring in international expertise and good practices in order to learn the best ways and methods of policy rationalization and capacity development of institutions and individuals.

The key responsibility lies with the Ministry of Planning and Investment (MPI) to lead other ministries such as MoIT, MOLISA, MOET, Ministry of Nature Resources and Environment, and Ministry of Construction along with ADB, World Bank, and ILO.

\section{Provide Direct and Indirect Incentives to Promote Green Skills}

Direct financial incentives in the form of tax breaks, subsidies, viability gap funding, and innovation funds for the private sector to move toward sustainable processes, thereby generating green jobs, are all important. It is also important for TVET institutions to be motivated to move toward green skills development. Enterprises offering green skills development training should be entitled to general incentives concerning vocational training under government regulations or be allowed to recover training expenses through users or sponsoring institutions. The government may further encourage indirect incentives by providing land, training equipment, international exposure visits, and industrial exposure for TVET staff.

The key responsibility is with the Ministry of Finance (MOF), along with MoIT, MOLISA, and MOET.

\section{Promote Green and Sustainable Practices as a Key Business Issue}

The pressure of achieving business targets and meeting stiff competition, often pushes the issues of sustainability down the priority list. Businesses fail to realize that sustainable practices can solve problems of increasing costs, provide an edge over competitors, and enable compliance with climate change mandates. Greening should become a key business issue that is championed by larger companies. The benefits of adopting sustainable practices and upskilling the existing workforce also need to be communicated widely and strongly among SMEs through supply chains.

The key responsibility rests with large corporations such as the Hoa Phat Group, Doji Gold and Gems Group, and Vinamilk, and public sector corporations such as PetroViet Nam and Vinacomin.

\section{Coordinate Action Between Foreign Aid and Investment Agencies}

UNIDO has created a policy framework for green industry in Viet Nam; GTZ is supporting the "TVET reform project" at GDVT, with a special focus on Greening TVET; and, ILO, ADB, and other agencies are also working in skills development in a variety of ways. A number of MNCs are also investing in business and trade. 
Achieving coordinated action by the agencies can effectively and strongly push the importance of achieving transition toward sustainable practices and requirements for green skills development.

Documentation and dissemination of good practices (both national and international) can be supported by aid agencies, while MNCs may support models of innovation toward green practices and green education with private sector agencies and TVET institutions.

The key responsibility is with aid agencies such as ADB, the World Bank and $\mathrm{UN}$, and with MNCs.

\section{Encourage Green Skills Through Generic Content in All Forms of Education Curricula: School, Technical, and University}

Generic skills in training can contribute a progressive path to specific skills and courses. Content related to sustainable practices and climate change issues can be introduced into existing curricula, not just in TVET institutions but also in school and higher education institutions. Research in higher education becomes critical to helping provide direct guidance toward newer practices and technologies that are environmentally sustainable. Higher education institutions may also take the lead in the professional development of trainers through in-service training.

While institutional-level initiatives are quicker to implement, large-scale reforms may also be initiated simultaneously. For example, the National Skills Standard Developing Committee under MOLISA can not only develop and establish green standards but also dovetail these with existing National Skills Qualification Certification levels and National Occupational Standards.

The key responsibility is with the National Skills Standard Developing Committee along with MOLISA and MOET.

\section{Coordinate and Rationalize Private and Government Training Systems}

Training by the private sector is potentially important and should not be ignored. While reforms in government TVET providers are championed by the line ministries, reforms in the private sector can be pushed through by industry and employers. Parity in the quality of training, incentives, governance, and industry relevance is required between the two systems. In addition, the state should create a framework to accredit and recognize the various forms of vocational training undertaken by different enterprises.

The key responsibility lies with MOLISA and MOET together with large private sector corporations.

\section{Promote Greening as a Social Issue}

In addition to formal TVET, sensitivity toward the environment is often developed through social interaction and public communications. Green skills development should be understood not only as a matter of curriculum, and in terms of content limited to TVET institutions, but as something that should be built into the larger ecosystem of education, workplaces, social interactions, and political debates. 
All forms of media - print, radio, television, and social — can be encouraged to position convincing messages so that the community sees value in moving toward greener practices, with green skills development becoming a necessity rather than an option. NGOs and SHGs can be targeted with special green skills modules to reach out to involve women and marginalized groups, and to encourage them to develop green skills, which may or may not be employment-related skills.

The key responsibility is with GDVT under MOLISA and the Centre for Environmental Education and Communications.

\section{Expand the Scope of Green Jobs and Green Skills to the Informal and Rural Sectors}

Most engagement with industry and the government with respect to sustainable growth is limited to the formal, organized sector and addresses mainly urban issues. Research and policy also need to generate evidence concerning the needs and situation of environmentally sustainable jobs and skills in the informal economy. Activities include small-scale manufacturing, trading, and art and craftsmanship related to work in rural areas, especially with regard to agricultural processing and other nonfarm-related work.

The key responsibility rests with multilateral agencies such as ADB, the World Bank, and ILO, along with research institutions and universities.

The views expressed in this publication are those of the authors and do not necessarily reflect the views and policies of the Asian Development Bank (ADB) or its Board of Governors or the governments they represent.

ADB does not guarantee the accuracy of the data included in this publication and accepts no responsibility for any consequence of their use. The mention of specific companies or products of manufacturers does not imply that they are endorsed or recommended by ADB in preference to others of a similar nature that are not mentioned.

By making any designation of or reference to a particular territory or geographic area, or by using the term "country" in this document, ADB does not intend to make any judgments as to the legal or other status of any territory or area.

Open Access This work is available under the Creative Commons Attribution 3.0 IGO license (CC BY 3.0 IGO) https://creativecommons.org/licenses/by/3.0/igo/. By using the content of this publication, you agree to be bound by the terms of this license. For attribution, translations, adaptations, and permissions, please read the provisions and terms of use at https://www.adb.org/ terms-use\#openaccess This CC license does not apply to non-ADB copyright materials in this publication. If the material is attributed to another source, please contact the copyright owner or publisher of that source for permission to reproduce it. ADB cannot be held liable for any claims that arise as a result of your use of the material.

Please contact pubsmarketing@adb.org if you have questions or comments with respect to content, or if you wish to obtain copyright permission for your intended use that does not fall within these terms, or for permission to use the ADB logo.

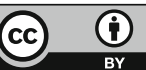

